\title{
Minat Beli Online Generasi Milenial: Pengaruh Kepercayaan dan Kualitas Layanan
}

\author{
Kharis Fadlullah Hana \\ Institut Agama Islam Negeri Kudus \\ kharis@iainkudus.ac.id
}

\begin{abstract}
Buying and selling online is a transaction that is in high demand by the current millennial generation. The ease, efficiency, variety of choices and various promotions offered are the underlying factors for millennials to make online purchases. This can also be seen from the shift in the style of buying the younger generation from traditional markets to online stores that are increasing. Despite the many advantages and advantages offered, there are some consumers who are less satisfied with their purchases online. That is caused by poor service quality because sometimes the response from the seller to the buyer is quite long. Some sellers who give goods that are not in accordance with the offer also cause public confidence to decline. Based on these phenomena, this study aims to determine the effect of service quality and trust in millennial generation consumers' buying decisions and decisions. This research method uses quantitative methods with a Post positivism approach with Structural Equation Model analysis techniques using the WarpPls 6.0 analysis tool. Service quality and trust as exogenous variables, buying interest and online purchasing decisions as endogenous variables. The object of this research is millennial consumers in the cities of Kudus, Jepara and Pati who purchase goods online with a total sample of 375 respondents. The results showed that trust through interest influenced the online buying decision of 0.293. Trust and interest have a total influence of 0.402. Quality of service through interest affects the decision of 0.143. Service quality and interest have a total influence on online buying decisions of 0.363. This means that trust has a greater influence on buying decisions on digital generation compared to service quality.
\end{abstract}

Keywords: service quality, trust, and online purchasing interest

\begin{abstract}
Abstrak
Jual beli online merupakan transaksi yang sangat diminati oleh generasi milenial saat ini. Kemudahan, efisiensi, beragam pilihan dan berbagai promosi yang ditawarkan menjadi faktor yang melatarbelakangi kalangan milenial untuk melakukan pembelian secara online. Hal ini juga dapat dilihat dari pergeseran gaya beli generasi muda dari pasar tradisional ke toko online yang semakin meningkat. Meskipun banyak keuntungan dan kelebihan yang ditawarkan, namun ada beberapa konsumen yang kurang puas atas pembelian mereka secara online. Hal itu disebabkan oleh kualitas pelayanan yang kurang karena terkadang respon dari penjual kepada pembeli cukup lama. Beberapa penjual yang memberikan barang yang tidak sesuai dengan penawarannya juga menimbulkan kepercayaan masyarakat menurun. Berdasarkan fenomena tersebut maka, penelitian ini bertujuan untuk mengetahui pengaruh kualitas pelayanan dan kepercayaan terhadap minat dan keputusan beli konsumen generasi milenial. Metode penelitian ini menggunakan metode kuantitatif dengan pendekatan Post positivisme dengan teknik analisis Structural Equation Model menggunakan alat analisis WarpPls 6.0.
\end{abstract}


Kualitas pelayanan dan kepercayaan sebagai variabel eksogen, minat beli dan keputusan beli online sebagai variabel endogen. Obyek penelitian ini adalah konsumen milenial di kota Kudus, Jepara dan Pati yang melakukan pembelian barang secara online dengan jumlah sampel sbanyak 375 responden. Hasil penelitian diperoleh bahwa kepercayaan melalui minat berpengaruh terhadap keputusan beli online sebesar 0,293. Kepercayaan dan minat mempunyai pengaruh total sebesar 0,402. Kualitas pelayanan melalui minat berpengaruh terhadap keputusan sebesar 0,143. Kualitas pelayanan dan minat mempunyai pengaruh total terhadap keputusan beli online sebesar 0,363. Artinya kepercayaan memiliki pengaruh lebih besar terhadap keputusan beli online generasi milenial dibandingkan dengan kualitas layanan.

Kata kunci: kualitas layanan, kepercayaan dan minat beli online

\section{PENDAHULUAN}

Perkembangan dunia internet saat ini semakin massif dan menjangkau ke berbagai kalangan. Pengguna terbanyak adalah generasi muda atau yang sekarang disebut sebagai generasi milenial. Generasi milenial atau yang disebut juga sebagai Gen Y merupakan generasi yang lahir pada tahun 19802000 dengan usia saat ini antara 19 s.d 39 tahun (Hidayatullah, Waris, \& Devianti, 2018). Mereka terlahir di era teknologi yang sudah berkembang, era dimana komputer, handphone, smartphone mulai diciptakan. Mereka merupakan generasi yang lebih memilih cara instan dalam melakukan pekerjaan. Apalagi masa muda mereka disajikan teknologi yang dapat mengakses informasi apapun di dunia yaitu teknologi internet (Kurniawati, 2015). Internet yang semula pada tahun 2000 hanya dapat diakses melalui komputer, sekarang dapat diakses melalui smartphone yang mereka pegang setiap waktu. Kebiasaan mereka yang lebih sering membawa smartphone dimanapun dan kapanpun membuat akses informasi yang mudah dan cepat terutama untuk mengakses barang kebutuhan yang diperlukan. Kebutuhan seperti pakaian, makanan, smartphone dan laptop merupakan barang yang menempati peringkat utama di daftar penjualan barang online.

Pembelian barang online oleh para pembeli milenial dilakukan melalui dua cara, yang pertama adalah melalui social commerce dan yang kedua adalah ecommerce. Social commerce merupakan pembelian online melalui media social yang dipunyai seperti facebook, instagram dan twitter (Khairani, Soviyant, \& Aznuriandi, 2018). Pada social commerce pembeli hanya perlu membuat akun yang disediakan secara gratis. Mereka tinggal melihat barang yang dibutuhkan melalui grup ataupun akun penyedia produk yang diinginkan, namun kekurangannya adalah tidak ada transparansi pembayaran dan pengrimannya, tidak ada garansi dan sulit mengukur kredibilitas. Pembelian barang melalui e-commerce yang mulai banyak di minati generasi milenial saat ini. Berbagai promo yang ditawarkan, jaminan resmi, transparansi pengiriman, dan dapat melihat kredibilitas penjual. Apalagi didukung dengan pembuatan akun yang gratis dan beragam produk yang disediakan. 
E-commerce merupakan proses transaksi barang atau jasa melalui sistem informasi yang memanfaatkan teknologi internet. E-commerce yang sering digunakan oleh generasi milenial adalah e-commerce jenis market place. Secara sederhana, e-commerce jenis market place merupakan suatu tempat dimana pembeli dapat membuat akun dan memilih berbagai macam barang yang disediakan (Alwafi \& Magnadi, 2016). E-commerce jenis market place yang ada di Indonesia antara lain tokopedia.com, bukalapak.com, bli-bli.com, shopee.com dll. Toko online yang paling digemari oleh generasi milenial adalah shopee dan buka lapak karena menawarkan promo dan beragam barang yang murah di bandingkan dengan toko online lainnya. Mereka sering memesan kebutuhan sehari-hari seperti makanan, fashion, dan buku bacaan. Meskipun minat generasi milenial yang cukup tinggi akan pembelian barang secara online, namun pesanan yang kurang sesuai dengan yang diharapkan dan respon dari penjual online yang lama menjadi permasalahan yang perlu dilakukan perbaikan.

Faktor kepercayaan merupakan faktor kunci dari sekian banyak faktor yang mempengaruhi terjadinya transaksi jual beli secara online. Hanya pelanggan yang memiliki kepercayaan yang berani melakukan transaksi pembelian secara online (Siagian \& Cahyono, 2014). Mereka hanya mendapatkan informasi barang dan penjual, namun belum mengetahui secara jelas kredibilitas penjual. Tanpa adanya kepercayaan dari pembeli, mustahil transaksi melalui online terjadi. Hal ini sesuai dengan penelitian (Nusarika \& Purnami, 2015) kepercayaan berpengaruh positif dan signifikan terhadap niat beli produk online di kota Denpasar. Berdasarkan penelitian (Sugara \& Dewantara, 2017) juga menyatakan bahwa kepercayaan berpengaruh terhadap penggunaan sistem transaksi jual beli pada konsumen "Z" yang artinya kepercayaan dapat meningkatkan transaksi jual beli online.

Berdasarkan penelitian (Siagian \& Cahyono, 2014) (Sadeh, Sadeh, Mousavi, \& Asgari, 2011) menyatakan bahwa pemilik toko online harus memberikan pelayanan yang terbaik diantaranya adalah dengan memperbaiki situs web untuk meyakinkan pengunjung dan mendapatkan kepercayaan sehingga menimbulkan loyalitas pelanggan. Hal ini juga didukung oleh penelitian (Parasuraman, V, \& Berry, 1998) bawa kualitas layanan online yang baik akan membuat layanan menjadi efektif dan menarik sehingga membantu perusahaan dalam pencapaian tertinggi pada level kepuasan pelanggan. Penelitian lainnya (Setyarko, 2016) juga menyebutkan kualitas layanan berpengaruh positif dan signifikan terhadap keputusan pembelian, keputusan pembelian merupakan serangkaian proses yang dipengaruhi oleh adanya pengaruh kualitas layanan yang diberikan oleh penjual seperti keramahan, tanggapan yang baik dan cepat, serta jaminan ketersediaan barang. Berdasarkan berbagai fenomena yang terjadi dan penelitian sebelumnya yang menyatakan bahwa kualitas layanan dan kepercayaan berpengaruh terhadap keputusan pembelian maka penelitan ini bertujuan untuk menguji pengaruh kepercayaan dan kualitas layanan yang diberikan 
toko online dalam mempengaruhi minat dan keputusan pembelian barang secara online.

\section{KAJIAN LITERATUR}

Generasi milenial merupakan generasi yang lahir dalam rentang waktu awal tahun 1980 sampai dengan tahun 2000. Generasi ini sering disebut sebagai Gen-Y, Net Generation, Generation WE, Peterpan Generation, Boomerang Generation dan lain-lain. Berdasarkan hasil penelitian (Hidayatullah et al., 2018) Generasi Y dikenal sebagai generasi milenial. Generasi ini mulai banyak menggunakan teknologi komunikasi instan seperti email, SMS, facebook dan media social lainnya dengan kata lain generasi Y ini merupakan generasi yang tumbuh pada era internet booming. Mereka lahir di era teknologi sehingga mempengaruhi perilaku yang amat sangat tergantung dengan teknologi. Mereka bergantung pada internet dengan smartphone yang mereka pakai untuk mencari beragam informasi termasuk mengumpulkan informasi sebelum mengambil keputusan pembelian suatu produk yang diinginkan. Gaya hidup milenial yang konsumtif dan cenderung malas membuat penyedia menawarkan beragam produk mereka melalui online (Hidayatullah et al., 2018). Hal ini membuat mereka lebih memilih membeli barang melalui toko online atau yang disebut dengan e-commerce. E-commerce merupakan suatu proses transaksi jual beli barang atau jasa melalui sistem informasi yang memanfaatkan teknologi internet.

Menurut Sutabri (2012) e-commerce adalah penyebaran, pembelian, penjualan, pemasaran barang atau jasa melalui sistem internet. E-commerce dapat berupa transfer dana elektronik, peralihan data elektronik, sistem inventori otomatis dan sistem pengumpulan data otomatis. Jaringan utama yang digunakan pada toko online adalah internet. Internet telah mengubah pola perdagangan dalam dunia bisnis saat ini menjadi serba digital (Anwar \& Adidarma, 2016). Mekanisme transaksi bisnis saat ini dibangun dalam komunitas berjejaring internet. Secara pelan namun pasti, penawaran dari teknologi internet telah mengubah perilaku pembelian generasi milenial dalam memenuhi kebutuhannya.

Pembelian online merupakan proses dimana konsumen secara langsung membeli barang atau jasa yang ditawarkan dari seorang penjual secara interaktif dan real time melalui media perantara yaitu internet (Mujiyana \& Elissa, 2013). Pembelian online atau belanja secara online seorang pembeli dapat melihat terlebih dahulu barang atau jasa yang hendak ia belanjakan melalui web ataupun toko online yang dipromosikan oleh penjual. Kegiatan pembelian online ini merupakan bentuk transaksi baru yang tidak memerlukan transaksi tatap muka secara langsung melainkan dapat dilakukan secara terpisah dari dan ke seluruh dunia melalui smartphone. Terlepas dari semakin mudahnya konsumen melakukan pembelian online sebagai akibat dari perkembangan teknologi internet, namun demikian ada risiko yang harus dihadapi khususnya adalah dalam hal kepercayaan. Kasus penipuan yang beberapa kali dihadapi oleh para konsumen membuat faktor 
kepercayaan menjadi hal yang sangat diperhatikan oleh konsumen online. Menurut (Kim, Ferrin, \& Rao, 2008) dalam penelitiannya menemukan bahwa faktor kepercayaan memiliki pengaruh kuat pada minat beli yang berujung pada keputusan pembelian oleh konsumen.

\section{Kepercayaan}

Dalam dunia jual beli online, kepercayaan merupakan salah satu faktor utama yang harus dibangun oleh pelaku transaksi bisnis online. Adanya kepercayaan yang dibangun oleh para pelaku bisnis akan mendorong minat konsumen untuk berbelanja online melalui toko online ataupun website yang dibangun sendiri (Harris \& Goode, 2010). Kepercayaan merupakan suatu pondasi dalam menjalankan sebuah bisnis. Suatu transaksi antara dua orang atau lebih akan terjadi apabila kedua belah pihak saling percaya (Anwar \& Adidarma, 2016). Kepercayaan dalam dunia bisnis tidaklah muncul secara instan, melainkan harus dibangun sejak awal bisnis berdiri. Menurut (Hsiao \& Tsai, 2018) dalam penelitiannnya mendefinisikan kepercayaan terhadap situs jual beli online sebagai kesediaan konsumen dalam mempercayai situs jual beli online. Keberhasilan transaksi online sangat dipengaruhi oleh faktor kepercayaan (Pavlou, 2003). Menurut (Firdayanti, 2012) kepercayaan konsumen merupakan presepsi dari sudut pandang konsumen tentang kehandalan penjual dalam pengalaman dan terpenuhinya harapan sehingga menimbulkan kepuasan konsumen.

Berdasarkan penelitian (McKnight \& Chervany, 2001) menyatakan bahwa kepercayaan merupakan sebuah konsep yang sangat luas. Dalam elaborasinya yang lebih lanjut (McKnight \& Chervany, 2001) menjelaskan bahwa secara rinci komponen kepercayaan dibagai menjadi beberapa instrument. Pertama adalah integritas, integritas merupakan kemampuan menepati janji dari pihak penjual. Integritas erat kaitannya dengan bagaimana perilaku atau kebiasaan penjual dalam menjalankan transaksi bisnisnya. Integritas dapat dilihat dari sudut keterbukaan, pemenuhan, kesetiaan, kejujuran, keterkaitan dan kehandalan. Kedua benevolence (kebaikan hati), merupakan perhatian dan motivasi untuk bertindak sesuai dengan kepentingan konsumen oleh penjual (penyedia barang). Kebaikan hati merupakan kemauan penjual dalam memberikan kepuasan untuk saling menguntungkan antara peneyedia barang dan konsumen. Penjual bukan semata-mata mengejar keuntungan maksimal semata, namun memiliki perhatian yang besar dalam memenuhi kepuasan konsumen. Indikator dari kebaikan hati meliputi perhatian, empati, keyakinan dan daya terima. Ketiga competency, merupakan kemampuan penjual untuk melaksanakan kebutuhan yang diinginkan konsumen. Hal ini berarti bagaimana penjual mampu menyediakan, melayani sampai mengamankan transaksi dari gangguan pihak lain. Konsumen memperoleh jaminan kepuasan dan keamanan dari penjual dalam melakukan transaksi. Indikatornya meliputi pengalaman, pengesahan institusional, dan kemampuan dalam ilmu pengetahuan. Keempat adalah predictability, merupakan konsistensi perilaku 
oleh penyedia barang (penjual). Kemampuan penjual untuk memberikan kepastian akan barang yang dijual, sehingga konsumen dapat mengantisipasi dan memprediksi kinerja penjual. Indikatornya meliputi citra diri dari penjual, risiko yang mampu diprediksi dan konsistensi. Berbagai indikator itulah yang mempengaruhi minat beli konsumen.

\section{Kualitas Layanan Online}

Kualitas layanan saat ini dihadapkan dengan layanan yang harus mengikuti perkembangan jaman di era 4.0 yaitu teknologi internet. Kualitas layanan online pada dunia online merupakan sesuatu yang penting dalam menentukan kesuksesan atau kegagalan pada perdagangan elektronik (Kuspriyono, 2017). Menurut (Sousa \& Voss, 2009) mendefinisikan layanan online sebagai "the delivery as service using new media such as the web". Pengertian tersebut berarti penyerahan barang atau jasa dengan menggunakan media yang baru yaitu website. Keberadaan bukti dari kualitas layanan atas penyerahan barang atau jasa melalui website merupakan kesuksesan strategi yang sangat penting dibandingkan dengan harga murah dan keberadaan web. Berdasarkan penelitian (Parasuraman et al., 1998) mendefinisikan kualitas layanan online (e-service quality) dalam interaksinya dengan website "the extent to which a website facilities efficient and effective shopping, purchasing and delivery". Artinya bahwa kualitas pelayanan online merupakan suatu tingkat sebuah website secara efektif dan efisien memfasilitasi pelanggan dalam hal pembelian barang atau jasa. Penilaian dari kualitas website bukan hanya terletak pada pengalaman selama melakukan interaksi dengan web tersebut, namun juga interaksi setelah mendapatkan layanan yang baik. Kualitas layanan pada dunia internet merupakan hal penentu yang penting sebagai efektifitas dari proses e-commerce. Standar tertinggi dari kualitas layanan online berarti keuntungan potensial dari internet dapat direalisasikan. Semakin berkembangnya kualitas layanan online membuat layanan online lebih menarik sehingga membantu perusahaan ataupun toko online dalam mencapai mencapai minat beli sehingga menimbulkan keputusan dan mewujudkan titik tertinggi yaitu kepuasan pelanggan.

\section{Minat Beli Online}

Hasil Penelitian yang dilakukan oleh (Kim et al., 2008) menemukan bahwa terdapat hubungan antara niat dan keputusan pembelian. Hubungan tersebut didasarkan pada manusia selalu berusaha untuk membuat keputusan yang rasional berdasarkan berdasarkan tingkat informasi yang tersedia bagi mereka. Dengan demikian, niat seseorang untuk membeli atau tidak membeli adalah penentuan langsung dari tindakan aktual yang dilakukan oleh orang tersebut. Berdasarkan hubungan tersebut (Kim et al., 2008) menegaskan bahwa minat dalam melakukan pembelian merupakan perkiraan dari keputusan tindakan atau pembelian aktual yang dilakukan oleh konsumen. Menurut (Binalay, Mandey, \& Minatrdjo, 2016) menyatakan bahwa yang 
dimaksud dengan minat beli konsumen adalah suatu proses perencanaan pembelian suatu produk yang dilakukan oleh konsumend dengan mempertimbangkan beberapa faktor, yang pertama adalah berapa banyak unit produk yang diperlukan dalam periode waktu tertentu, merek dan sikap konsumen dalam membeli barang tersebut. Sedangkan, Menurut (Maulana \& Kurniawati, 2014), menjelaskan bahwa minat beli diperoleh dari suatu proses belajar dan proses pemikiran yang membentuk presepsi. Minat yang muncul dalam keputusan pembelian menciptakan suatu motivasi yang terus tersimpan dalam benaknya dan menjadi kegiatan yang sangat kuat pada akhirnya ketika seorang konsumen harus memenuhi kebutuhannya untuk merealisasikan apa yang ada dalam pikirannya itu. Minat pembelian (Anwar \& Adidarma, 2016) yang dilakukan pada media online merupakan keinginan untuk membeli suatu produk atau jasa yang ditawarkan oleh penjual kepada konsumen melalui media online.

\section{METODE PENELITIAN}

Metode penelitian yang digunakan dalam penelitian ini adalah penelitian kuantitatif dengan teknik pengambilan sampel non probability sampling yaitu purposive random sampling (Sugiyono, 2014). Sampel dipilih dari populasi generasi milenial di kabupaten Kudus, Pati dan Jepara yang melakukan pembelian secara online. Kuisioner disebarkan melalui link google form dengan indikator kepercayaan adalah keamanan, kerahasiaan dan kompensasi dengan 4 item pertanyaan. Indikator kualitas layanan yaitu ketepatan janji, kejelasan informasi, sikap professional dan ketepatan waktu dengan 5 item pertanyaan. Minat beli dengan indikator preferensi, keinginan, kebutuhan dan pencarian informasi dengan 4 item pertanyaan. Keputusan pembelian dengan indikator kebutuhan, pencarian informasi, alternative, keyakinan dan kepuasan dengan 5 item pertanyaan. Skala pengukurannya adalah menggunakan skala likert interval 1 sampai dengan 5 dengan jawaban sangat tidak setuju, tidak setuju, ragu-ragu, setuju dan sangat setuju.

Teknik pengukurannnya menggunakan model structural equational model (SEM) dengan variabel kualitas layanan dan kepercayaan sebagai variabel eksogen, minat beli dan keputusan pembelian barang online sebagai variabel endogen. Alat ukur yang digunakan yaitu warpPLS 6.0. WarpPLS 6.0 merupakan aplikasi untuk model persamaan structural untuk menguji secara simultan hubungan antar konstruk laten dalam hubungan linear baik berbentuk reflektif ataupun formatif (Haryono, 2014) (Kock, 2014). Model pengukurannya adalah dengan kriteria indikator reliability menggunakan parameter significant weight dengan $\mathrm{p}$ value $<0,05$. Collinearity menggunakan VIF $<5$ dan tolerance $>0,2$. Dalam menguji variabel tidak langsung digunakan landasan $\mathrm{VAF}>80 \%$ maka full mediation, $20 \%<\mathrm{VAF}<$ $80 \%$ partial mediation, VAF $<20 \%$ maka no effect mediation. Uji kesesuaian antara model teoritis dan data empiris dapat dilihat pada tingkat (Goodnessof-fit statistic) (Barrett, 2007). Suatu model dikatakan fit apabila kovarians 
matriks suatu model adalah sama dengan kovarians matriks data (observed) (Ghozali, 2009).

\section{PEMBAHASAN}

Hasil pengumpulan data dari sampel berjumlah 375 responden kemudian diolah dengan menggunakan aplikasi WarpPLS 6.0 dengan merumuskan variabel kepercayaan dan kualitas layanan sebagai variabel eksogen, minat dan keputusan pembelian menjadi variabel endogen. Rumusan variabel tersebut kemudian menghasilkan model gambar berikut ini:

Gambar 1. Model Kepercayaan, Kualitas layanan, Minat dan Keputusan

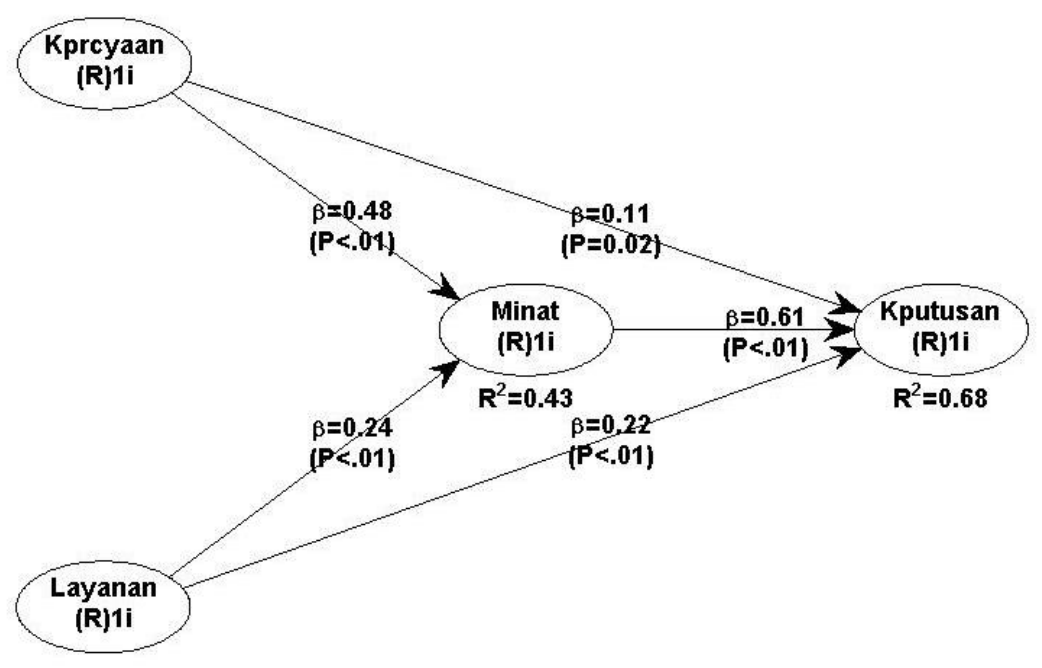

Dari model tersebut dapat dijelaskan hipotesis dalam penelitian yang dirumuskan adalah sebagai berikut ini:

H1 = Kepercayaan berpengaruh terhadap minat pembelian barang online H2 = Kepercayan berpengaruh terhadap keputusan pembelian barang online H3 = Kualitas layanan berpengaruh terhadap minat pembelian barang online $\mathrm{H} 4$ = Kualitas layanan berpengaruh terhadap keputusan pembelian barang online

H5 = Minat berpengaruh terhadap keputusan pembelian barang online H6 = Kepercayaan berpengaruh terhadap minat dan berpengaruh terhadap keputusan pembelian

$\mathrm{H7}=$ Kualitas layanan berpengaruh terhadap minat dan berpengaruh terhadap keputusan pembelian barang secara online.

Tabel 1. Model Fit

\begin{tabular}{|c|c|c|c|}
\hline Average path coefficient (APC) & 0,331 & Probability & $<0,001$ \\
\hline Average R-squared (ARS) & 0,550 & Probability & $<0,001$ \\
\hline $\begin{array}{l}\text { Average adjusted } \\
\text { (AARS) }\end{array}$ & 0,548 & Probability & $<0,001$ \\
\hline Average block VIF (AVIF) & 1,676 & $\begin{array}{l}\text { acceptable if } \leq \\
5\end{array}$ & ideally $\leq 3,3$ \\
\hline
\end{tabular}


Minat Beli Online Generasi Milenial: Pengaruh Kepercayaan dan Kualitas Layanan

\begin{tabular}{l|l|l}
\hline $\begin{array}{l}\text { Average full collinearity VIF } \\
\text { (AFVIF) }\end{array}$ & 2,395 & $\begin{array}{l}\text { acceptable if } \leq \text { ideally } \leq 3,3 \\
5\end{array}$ \\
\hline Tenenhaus GoF (GoF) & 0,742 & $\begin{array}{l}\text { small } \geq 0,1, \text { medium } \geq 0,25, \\
\text { large } \geq 0,36\end{array}$ \\
\hline Sympson's paradox ratio (SPR) & 1.000 & $\begin{array}{l}\text { acceptable if } \geq \text { ideally }=1 \\
0,7\end{array}$ \\
\hline $\begin{array}{l}\text { R-squared contribution ratio } \\
\text { (RSCR) }\end{array}$ & 1.000 & $\begin{array}{l}\text { acceptable if } \geq \text { ideally }=1 \\
0,9\end{array}$ \\
\hline $\begin{array}{l}\text { Statistical suppression ratio } \\
\text { (SSR) }\end{array}$ & 1.000 & acceptable if $\geq 0,7$ \\
\hline $\begin{array}{l}\text { Non linear bivariate causality } \\
\text { direction ration (NLBCR) } \\
\text { Sumber: Output WarpPLS 6.0 }\end{array}$ & 1.000 & acceptable if $\geq 0,7$ \\
\hline
\end{tabular}

Model penelitian setelah dilakukan analisis data adalah fit yang ditunjukkan sebagaimana Tabel 1. Nilai rata-rata koefisien jalur (average path coefficient) $\mathrm{APC}=0,331$ dengan $\mathrm{p}<0,001$. Nilai rata-rata $\mathrm{R} 2$ (average $R$-squared $(\mathrm{ARS}$ ) $=$ 0,550 dengan $\mathrm{p}<0,001$ dan nilai rata-rata $\mathrm{R} 2$ yang disesuaikan AARS (average adjusted $R$-squared) $=0,548$ dengan $\mathrm{p}<0,001$ yang berarti signifikan karena lebih kecil dari 0,05. Begitu juga dengan nilai average block VIF (AVIF) sebesar 1,676 dan average full collinearity (AFVIF) yang dihasilkan 2,395 < 3,3 , yang berarti bahwa tidak ada masalah multikolinearitas antar indikator dan antar variabel eksogen (Barrett, 2007). Nilai evaluasi kecocokan model (Tenenhaus Goodness of Fit) GoF $=0.742$ yang berarti memiliki kecocokan tinggi karena lebih besar dari 0.36. Nilai perbandingan paradoks Symson (Sympson's Paradox Ratio) SPR $=1$. Nilai perbandingan kontribusi R2 ( $R$-Squared Contribution Ratio) RSCR $=1$. Untuk indeks Symson's Paradox Ratio (SPR), R-Squared Contribution Ratio (RSCR) dan Nonlinear Bivariate Causality Direction Ratio (NLBCDR) menghasilkan nilai > 0.7 yaitu 1, yang berarti tidak ada problem kausalitas didalam model. Sedangkan untuk indeks Statistical Suppression Ratio (SSR) menghasilkan nilai 1 yang berarti dapat diterima.

Tabel 2. Hasil output latent variabel coefficient

\begin{tabular}{l|l|l|l|l}
\hline & Kepercayaan & Layanan & Minat & Keputusan Beli \\
\hline R-Squared & & & 0,425 & 0,675 \\
\hline Adj. R-squared & & & 0,422 & 0,673 \\
\hline Composite reliabel & 1,000 & 1,000 & 1,000 & 1,000 \\
\hline Cronbach's alpha & 1,000 & 1,000 & 1,000 & 1,000 \\
\hline Avg. var. extrac. & 1,000 & 1,000 & 1,000 & 1,000 \\
\hline Full Collin. VIF & 1,946 & 1,777 & 2,818 & 3,040 \\
\hline Q-Squared & & & 0,426 & 0,676
\end{tabular}

Sumber: Output WarpPLS 6.0 
Dari tabel diatas menunjukkan bahwa koefisien adjusted R-squared untuk variabel kepercayaan dan layanan dapat menjelaskan minat beli online sebesar 42,2\%, sisanya dipengaruhi oleh variabel lain. Sedangkan untuk koefisien adjusted R-squared variabel kepercayaan, kualitas layanan dan minat dapat menjelaskan keputusan pembelian online sebesar 67,3\%, sisanya dipengarui oleh variabel lain.

Tabel. 3 Hasil Uji Signifikansi koefisien jalur

\begin{tabular}{l|l|l|l|l|l|l}
\hline $\mathrm{H}$ & Jalur & $\beta$ & $\rho$ & $\begin{array}{l}\text { Standar } \\
\text { Error }\end{array}$ & $\begin{array}{l}\text { Effect } \\
\text { Size }\end{array}$ & Hasil \\
\hline $\mathrm{H} 1$ & $\begin{array}{l}\text { Kepercayaan -> } \\
\text { Minat }\end{array}$ & 0,484 & $<0,001$ & 0,048 & 0,302 & Sign. \\
\hline $\mathrm{H} 2$ & $\begin{array}{l}\text { Kepercayaan }-> \\
\text { Keputusan Beli } \\
\text { Online }\end{array}$ & 0,109 & 0,017 & 0,049 & 0,247 & Sign. \\
\hline $\mathrm{H} 3$ & $\begin{array}{l}\text { Kualitas Layanan -> } \\
\text { Minat }\end{array}$ & 0,236 & $<0,001$ & 0,050 & 0,103 & Sign. \\
\hline H4 & $\begin{array}{l}\text { Kualitas Layanan -> } \\
\text { Keputusan Beli } \\
\text { Online }\end{array}$ & 0,220 & $<0,001$ & 0,049 & 0,217 & Sign. \\
\hline H5 & $\begin{array}{l}\text { Minat -> Keputusan } \\
\text { Beli Online }\end{array}$ & 0,606 & $<0,001$ & 0,047 & 0,477 & Sign. \\
\hline H6 & $\begin{array}{l}\text { Kepercayaan -> } \\
\text { Minat -> Keputusan } \\
\text { Beli Online }\end{array}$ & 0,293 & $<0,001$ & 0,035 & 0,180 & Sign. \\
\hline H7 & $\begin{array}{l}\text { Kualitas Layanan -> } \\
\text { Minat -> Keputusan } \\
\text { Beli Online }\end{array}$ & 0,143 & $<0,001$ & 0,036 & 0,086 & Sign. \\
\hline
\end{tabular}

Sumber: Output WarpPLS 6.0

Hipotesis pertama yang diuji adalah pengaruh kepercayaan terhadap minat pembelian barang online. Rumusan hipotesis diperoleh bahwa terdapat pengaruh langsung kepercayaan terhadap minat sebesar 0,484 dengan probability $<0,001$ kurang dari 0,05 dengan nilai standar error sebesar 0,048 . Nilai effect size $0,302(>0,15)$. Dengan demikian $\mathrm{H} 1$ yang menyatakan bahwa terdapat pengaruh langsung kepercayaan terhadap minat diterima.

Hipotesis kedua yang diuji adalah pengaruh kepercayaan terhadap keputusan pembelian barang online. Rumusan hipotesis diperoleh bahwa tidak terdapat pengaruh langsung kepercayaan terhadap keputusan pembelian karena nilainya sebesar 0,109 dengan probability 0,017 $>0,001$ dengan nilai standar error sebesar 0,049. Nilai effect size 0,247 $(>0,15)$. Dengan demikian H2 yang menyatakan bahwa terdapat pengaruh langsung kepercayaan terhadap keputusan pembelian ditolak.

Hipotesis ketiga yang diuji adalah pengaruh kualitas layanan terhadap minat pembelian barang online. Rumusan hipotesis diperoleh bahwa terdapat 
pengaruh langsung kepercayaan terhadap minat sebesar 0,236 dengan probability $<0,001$ kurang dari 0,05 dengan nilai standar error sebesar 0,050. Nilai effect size 0,103 $(<0,15)$. Dengan demikian H3 yang menyatakan bahwa terdapat pengaruh langsung kualitas layanan terhadap minat diterima.

Hipotesis keempat yang diuji adalah pengaruh kualitas layanan terhadap keputusan pembelian barang online. Rumusan hipotesis diperoleh bahwa terdapat pengaruh langsung kepercayaan terhadap keputusan pembelian sebesar 0,220 dengan probability $<0,001$ kurang dari 0,05 dengan nilai standar error sebesar 0,049 . Nilai effect size $0,217(>0,15)$. Dengan demikian H4 yang menyatakan bahwa terdapat pengaruh langsung kepercayaan terhadap keputusan pembelian diterima.

Hipotesis kelima yang diuji adalah pengaruh minat terhadap keputusan pembelian barang online. Rumusan hipotesis diperoleh bahwa terdapat pengaruh langsung minat terhadap keputusan pembelian sebesar 0,606 dengan probability $<0,001$ kurang dari 0,05 dengan nilai standar error sebesar 0,047 . Nilai effect size $0,477(>0,15)$. Dengan demikian H5 yang menyatakan bahwa terdapat pengaruh langsung minat terhadap keputusan pembelian diterima.

Hipotesis keenam yang diuji adalah pengaruh tidak langsung kepercayaan terhadap keputusan pembelian melalui minat. Rumusan hipotesis diperoleh bahwa terdapat pengaruh tidak langsung kepercayaan terhadap keputusan pembelian melalui minat sebesar 0,293 dengan probability $<0,001$ kurang dari 0,05 dengan nilai standar error sebesar 0,035. Nilai effect size 0,180 (> 0,15). Dengan demikian H6 yang menyatakan bahwa terdapat pengaruh tidak langsung kepercayaan terhadap keputusan terhadap minat diterima.

Hipotesis ketujuh yang diuji adalah pengaruh kualitas layanan terhadap keputusan pembelian melalui minat. Rumusan hipotesis diperoleh bahwa terdapat pengaruh tidak langsung kualitas layanan terhadap keputusan melalui minat sebesar 0,143 dengan probability $<0,001$ kurang dari 0,05 dengan nilai standar error sebesar 0,036. Nilai effect size $0,086(>0,15)$. Dengan demikian $\mathrm{H7}$ yang menyatakan bahwa terdapat pengaruh langsung kualitas pelayanan terhadap keputusan pembelian melalui minat diterima.

Tabel. 4 Hasil Total effect koefisien jalur

\begin{tabular}{l|l|l|l|l|l|l}
\hline No & Jalur & $\beta$ & $\rho$ & $\begin{array}{l}\text { Standar } \\
\text { Error }\end{array}$ & $\begin{array}{l}\text { Effect } \\
\text { Size }\end{array}$ & Hasil \\
\hline 1 & $\begin{array}{l}\text { Kepercayaan -> } \\
\text { Minat -> Keputusan } \\
\text { Beli Online }\end{array}$ & 0,402 & $<0,001$ & 0,049 & 0,247 & Sign. \\
\hline 2 & $\begin{array}{l}\text { Kualitas layanan -> } \\
\text { Minat -> Keputusan } \\
\text { Beli Online }\end{array}$ & 0,363 & $<0,001$ & 0,049 & 0,217 & Sign. \\
\hline
\end{tabular}


Berdasarkan table total effect dapat dijelaskan bahwa kepercayaan mempunyai pengaruh total terhadap keputusan pembelian melalui minat sebesar 0,484, pengaruh langsung kepercayaan terhadap keputusan pembelian 0,109. Hal ini berarti pengaruh yang diberikan kepercayaan terhadap keputusan pembelian online melalui minat lebih besar daripada pengaruh langsung kepercayaan terhadap keputusan pembelian. Total pengaruh kualitas pelayanan terhadap keputusan pembelian melalui minat adalah sebesar 0,363, pengaruh langsung kualitas pelayanan adalah sebesar 0,220 . Artinya, pengaruh yang diberikan kualitas layanan terhadap keputusan pembelian barang secara online melalui minat lebih besar daripada pengaruh langsung kepercayaan terhadap keputusan pembelian barang secara online.

Hasil penelitian yang telah dilakukan menunjukkan bahwa pengaruh kepercayaan lebih besar terhadap keputusan pembelian melalui minat lebih besar daripada pengaruh kualitas pelayanan melalui minat terhadap keputusan pembelian. Hal ini berarti generasi milenial melakukan proses keputusan pembelian barang online lebih menggunakan variabel kepercayaannya daripada kualitas layanan. Barang yang dikirim tidak sesuai dengan yang diharapkan membuat pertimbangan yang lebih lanjut dalam melakukan keputusan pembelian. Penjual harus meningkatkan komponen kepercayaan dari toko online mereka, komponen itu meliputi integritas, kebaikan hati, kompetensi, dan konsistensi.

\section{SIMPULAN}

Berdasarkan analisis penelitian yang dilakukan oleh peneliti dapat disimpulkan bahwa Kepercayaan mempunyai pengaruh tidak langsung terhadap keputusan pembelian melalui minat sebesar 0,293. Kualitas layanan mempunyai pengaruh tidak langsung terhadap keputusan pembelian melalui minat sebesar 0,143. Minat secara langsung memiliki pnegaruh terhadap keputusan pembelian sebesar 0,606. Artinya para generasi milenial akan berminat melakukan pembelian online berdasarkan tingkat kepercayaan dan kualitas layanan yang ditawarkan. Apabila generasi milenial sudah mempunyai minat akan pembelian online maka besar kemungkinannya akan melakukan keputusan pembelian karena pengaruh minat terhadap keputusan pembelian cukup besar. Hal ini perlu diperhatikan oleh penyedia barang ataupun penjual pada toko online bahwasannya mereka harus meningkatkan kepercayaan dan kualitas layanan yang mereka berikan.

\section{DAFTAR PUSTAKA}

Alwafi, F., \& Magnadi, R. H. (2016). Pengaruh Persepsi Keamanan, Kemudahan Bertransaksi, Kepercayaan Terhadap Toko dan Pengalaman Berbelanja Terhadap Minat Beli Secara Online Pada Situs Jual Beli Tokopedia.com. Diponegoro Journal Of Management, 5, 1-15.

Anwar, R., \& Adidarma, W. (2016). Pengaruh Kepercayaan dan Risiko Pada Minat Beli Belanja Online. Jurnal Manajemen Dan Bisnis Sriwijaya, 14(2). 
Minat Beli Online Generasi Milenial: Pengaruh Kepercayaan dan Kualitas Layanan

Barrett, P. (2007). Structural equation modelling: Adjudging model fit. 42, 815-824. https://doi.org/10.1016/j.paid.2006.09.018

Binalay, A. G., Mandey, S. L., \& Minatrdjo, C. M. O. (2016). Pengaruh Sikap, Norma Subjektif dan Motivasi Terhadap Minat Beli Secara Online Pada Mahasiswa Fakultas Ekonomi dan Bisnsi di Manado. Jurnal EMBA, 4(1), 395-406.

Firdayanti, R. (2012). Journal of Social and Industrial Psychology. 1(1), 1-7.

Ghozali, I. (2009). Aplikasi Analisis Multivariate Dengan Program SPSS (Cetakan IV). Semarang: Badan Penerbit Universitas Diponegoro.

Harris, L. C., \& Goode, M. M. H. (2010). Online servicescapes, trust, and purchase intentions. Journal of Services Marketing, 24(3), 230-243. https://doi.org/10.1108/08876041011040631

Haryono, S. (2014). Mengenal Metode Structural Equation Modeling (SEM) Untuk Penelitian Manajemen Menggunakan AMOS 18.00. Jurnal Ekonomi Dan Bisnis STIE YPN, VII(1), 23-34.

Hidayatullah, S., Waris, A., \& Devianti, R. C. (2018). Perilaku Generasi Milenial dalam Menggunakan Aplikasi Go-Food. Jurnal Manajemen Dan Kewirausahaan, 6(2), 240-249. https://doi.org/10.26905/jmdk.v6i2.2560

Hsiao, Y., \& Tsai, W. (2018). Financial literacy and participation in the derivatives markets. Journal of Banking and Finance, 88, 15-29. https://doi.org/10.1016/j.jbankfin.2017.11.006

Khairani, Z., Soviyant, E., \& Aznuriandi. (2018). Efektivitas Promosi Melalui Instagram Pada UMKM Sektor Makanan dan Minuman di Kota Pekanbaru. Jurnal Benefita, 3(2), 239-247.

Kim, D. J., Ferrin, D. L., \& Rao, H. R. (2008). A trust-based consumer decisionmaking model in electronic commerce: The role of trust, perceived risk, and their antecedents. Decision Support Systems, 44(2), 544-564. https://doi.org/10.1016/j.dss.2007.07.001

Kock, N. (2014). Advanced mediating effects tests, multi-group analyses, and measurement model assessments in PLS-based SEM. 1-13.

Kurniawati, D. (2015). Strategi Pemasaran Melalui Media Sosial dan Minat Beli Mahasiswa. Jurnal Simbolika, 1(2).

Kuspriyono, T. (2017). Pengaruh Kualitas Informasi Web dan Kualitas Layanan Online Terhadap Citra Bukalapak.com. Jurnal Perspektif, XV(1), $56-62$.

Maulana, R., \& Kurniawati, K. (2014). Pengaruh Kualitas E-Service Terhadap Minat Beli Konsumen (Studi Kasus Pada Website Koren Denim). Jurnal Manajemen, 13(2), 117-129.

McKnight, D. H., \& Chervany, N. L. (2001). Trust theory of relationship marketing. International Journal of Electronic Commerce, 6(2), 35-59.

Mujiyana, M., \& Elissa, I. (2013). Analisis Faktor-Faktor Yang Mempengaruhi Keputusan Pembelian Via Internet Pada Toko Online. J@Ti Undip : Jurnal Teknik Industri, 8(3), 143-152. https://doi.org/10.12777/jati.8.3.143152 
Nusarika, L. A. K., \& Purnami, N. M. (2015). Pengaruh Persepsi Harga, Kepercayaan, dan Orientasi Belanja Terhadap Niat Beli Secara Online (Studi pada Produk Fashion Online di Kota Denpasar). E-Jurnal Manajemen Unud, 4(8), 2380-2406.

Parasuraman, A., V, Z., \& Berry, L. (1998). SERVQUAL: A multiple-item scale for measuring consumer perceptions of Service Quality. Journal of Retailing, 6(September 2014), 12-37.

Pavlou, P. A. (2003). Consumer acceptance of electronic commerce: Integrating trust and risk with the technology acceptance model. International Journal of Electronic Commerce, 7(3), 101-134. https://doi.org/10.1080/10864415.2003.11044275

Sadeh, S., Sadeh, E., Mousavi, L., \& Asgari, F. (2011). The Effects of Website Quality Dimensions on Customer Satisfaction in E-Retailing System. Middle-East Journal of Scientific Research, 10(3), 366-369.

Setyarko, Y. (2016). Analisis Persepsi Harga, Promosi, Kualitas Layanan, dan Kemudahan Penggunaan Terhadap Keputusan Pembelian Produk Secara Online. Jurnal Ekonomika Dan Manajemen, 5(2), 128-147.

Siagian, H., \& Cahyono, E. (2014). Analisis Website Quality, Trust dan Loyalty Pelanggan Online Shop. Jurnal Manajemen Pemasaran, 8(2), 55-61. https://doi.org/10.9744/pemasaran.8.2.55-61

Sousa, R., \& Voss, C. A. (2009). The effects of service failures and recovery on customer loyalty in e-services: An empirical investigation. International Journal of Operations and Production Management, 29(8), 834-864. https://doi.org/10.1108/01443570910977715

Sugara, A., \& Dewantara, R. Y. (2017). Analisis Kepercayaan dan Kepuasan Terhadap Penggunaan Sistem Transaksi Jual Beli Online (Studi Pada Konsumen “ Z"). Jurnal Administrasi Bisnis (JAB), 52(1), 8-15.

Sugiyono. (2014). Statistika Untuk Penelitian. Bandung: Alfabeta. 